\title{
The Effectiveness Of Birthing Ball Therapy On The Duration Of The First Stage Of Labor And The Intensity Of Labor Pain In Primigravid Mothers Giving Births
}

\author{
Lilis Suryani*, Mufida Dian Hardika \\ Muhammadiyah Midwifery Academy of Madiun, Indonesia \\ *Lsuryani784@gmail.com
}

\begin{abstract}
The labor process is associated with labor pain. Several studies showed that labor in primitive communities is longer and painful, while $7-14 \%$ of advanced societies experience mild pain and the majority (90\%) experience severe pain. Health workers provide nonpharmacological therapeutic solutions. The birth ball is a therapy ball that assists in progress and relieves labor pain. This type of research is an observational analytic study with a cross-sectional design. The sampling technique used Simple Random Sampling. The sample size was 40 mothers with the division of 20 mothers used birthing ball therapy and 20 mothers did not use birthing ball therapy. Data collection tools were observation sheets. Data analysis was performed using Chi-Square and Multiple Logistic Regression analysis. There was a positive effect of using the Birth Ball with the duration of the first stage of labor of $(\mathrm{OR}=5.19 ; \mathrm{CI}=95 \% ; 1.06$ to $25.4 ; \mathrm{p}=0.042)$, the use of the Birth Ball with the intensity of labor pain of $(\mathrm{OR}=7.57$; $\mathrm{CI}=95 \% ; 1.53$ to $37.3 ; \mathrm{p}=0.013)$ and it was statistically significant. The use of a birthball has been shown to be effective in shortening the first stage of labor and reducing the intensity of pain.
\end{abstract}

Keywords : Birthing Ball Therapy, Duration of the First Stage of Labor, Labor Pain, Primigravid Mothers Giving Births 


\section{STRADA Jurnal Ilmiah Kesehatan}

DOI: $10.30994 /$ sjik.v9i2.404

ISSN: 2252-3847 (print); 2614-350X (online)

Vol.9 No.2 November 2020 Page.981-989

\section{BACKGROUND}

Labor is a physiological process, which is the process of releasing the product of conception from the uterus. The labor process is associated with labor pain (Prawirohardjo, 2008). Several studies showed that labor in primitive communities is longer and painful, while $7-14 \%$ of advanced societies experience mild pain and most of them (90\%) experience severe pain. Stress, anxiety, and worry are factors contributing to the perceived pain that affects labor and childbirth experiences (Runjati, 2018). Labor pain in the first stage of labor can be considered to be pain that lasts longer and is considered severe enough to be endured by most of the women giving births (Ade, 2017).

Labor pain and pain management remain a concern for women, families, and maternity health services. Health care providers pay special attention to this issue because it can be used as a reference to always use non-pharmacological measures to provide care to relieve labor pain (Gau, 2011). Numerous efforts were made to minimize labor pain, both pharmacologically and non-pharmacologically. Since pharmacological therapy is considered more expensive and has the potential to cause adverse effects, many nonpharmacological therapies can be used to minimize labor pain. It can be used by all levels of society affordably, easily, simply, effectively, and without any adverse effects. Based on research conducted in nine hospitals, 4.171 labors were assisted by nurses and midwives with a total of $90 \%$ choosing pain management by non-pharmacological methods (Nichols, 2000). One of the relaxation techniques and non-pharmacological measures in pain management during labor is using a birth ball (Yuliatun, 2008). The method of distraction with a birth ballcan minimize physiological pain, stress, and anxiety (Maurenne, 2005).

The birth ball is a physical therapy ball that assists in the first stage of the labor to the position that assists the labor progress. A physical therapy ball helps labor progress and can be used in various positions. One of the movements is to sit on the ball and rock it to make it feel comfortable and help labor progress by using gravity while increasing the release of endorphins in the pelvis which are responsible for secreting endorphins (Ade, 2017). The advantages of using this birthball are that it increases blood flow to the uterus, placenta, and baby; relieves pressure and can increase pelvic outlet by 30\%; provides comfort for knees and ankles; exerts counter-pressure on the perineum and thighs; works with gravity to encourage the descent of the baby thereby accelerating the labor process (Meurenne, 2005).

Based on the description above, the researcher was interested in examining whether there is a relationship between the use of birthing ball therapy with the duration of the first period of labor and the reduction of pain in the mothersgiving birth at the Independent Midwifery Practice of NinikWuryani, SST.

\section{METHODS}

This type of research was a quasi-experiment with a control group design. Research sampling was performed using the total sampling technique. The independent variable was birthing ball therapy, while the dependent variables were stage I of labor and the intensity of labor pain as measured by observation sheets and the measurement of the pain scale using the Wong-Baker Pain Rating Scale. Data analysis was performed using Chi-Square.

\section{RESULTS}

1. Frequency Distribution

a. Frequency Distribution of Birthball 


\section{STRADA Jurnal Ilmiah Kesehatan}

DOI: $10.30994 /$ sjik.v9i2.404

ISSN: 2252-3847 (print); 2614-350X (online)

Vol.9 No.2 November 2020 Page.981-989

Table 4.1 Frequency Distribution of Birthball

\begin{tabular}{lll}
\hline Category & Frequency & Percentage \\
\hline Usinga Birthball & 20 & 50 \\
Not Usinga Birthball & 20 & 50 \\
\hline Total & 40 & 100
\end{tabular}

Table 4.1 shows that the frequency distribution of using a birthball was 20 respondents (50\%)and not using a birthball was 20 respondents (50\%).

b. Frequency Distribution of Duration of the First Stage of Labor

Table 4.2 Frequency Distribution of Duration of the First Stage of Labor

\begin{tabular}{lll}
\hline Category & Frequency & Percentage \\
\hline$=<14$ Hours & 20 & 50 \\
$>14$ Hours & 20 & 50 \\
\hline Total & 40 & 100
\end{tabular}

Table 4.2 shows the frequency distribution of duration of the first stage of laborwas 20 respondents $(50 \%)$ for the duration ofthe first stage of laborforless than and equal to 14 hours and 20 respondents $(50 \%)$ for the duration of the first stage of laborfor more than 14 hours.

c. Frequency Distribution of Pain

Table 4.3 Frequency Distribution of Pain

\begin{tabular}{lll}
\hline Category & Frequency & Percentage \\
\hline Mild Pain & 21 & 53 \\
Severe pain & 19 & 47 \\
\hline Total & 40 & 100
\end{tabular}

Table 4.3 shows that the most frequency distribution was mild pain by 21 respondents (53\%) and severe pain by 19 respondents $(47 \%)$.

d. Frequency Distribution of Birth Ball with the Duration of the First Stage of Labor Table 4.4 Frequency Distribution of Birth Ball with the Duration of the First Stage of Labor

\begin{tabular}{lllll}
\hline & & \multicolumn{2}{l}{$\begin{array}{l}\text { The Duration of the First } \\
\text { Stage of Labor }\end{array}$} & \multirow{2}{*}{ Total } \\
\cline { 3 - 5 } & & $=<14$ Hours & $>14$ Hours & \\
\hline \multirow{3}{*}{ Birth Ball } & \multirow{2}{*}{ Using } & 15 & 5 & 20 \\
& & $37,5 \%$ & $12,5 \%$ & $50 \%$ \\
& \multirow{2}{*}{ NotUsing } & 5 & 15 & 20 \\
& & $12,5 \%$ & $37,5 \%$ & $50 \%$ \\
\hline \multirow{2}{*}{ Total } & 20 & 20 & 40 \\
& & $50 \%$ & $50 \%$ & $100 \%$
\end{tabular}

The relationship between Birthballs and the duration of the first stage of labor is distributed as follows:

1) Respondents who used birthballs were distributed as follows: 15 respondents $(37.5 \%)$ with the duration of the first stage of labor for less than and equal to 14 hours 


\section{STRADA Jurnal Ilmiah Kesehatan}

DOI: $10.30994 /$ sjik.v9i2.404

ISSN: 2252-3847 (print); 2614-350X (online)

Vol.9 No.2 November 2020 Page.981-989

and 5 respondents $(12.5 \%)$ with the duration of the first stage of labor for more than 14 hours

2) Respondents who did not use birthballs were distributed as follows: 5 respondents $(12.5 \%)$ with the duration of the first stage of labor for less than and equal to 14 hoursand 55 respondents $(37.5 \%)$ with the duration of the first stage of labor for more than 14 hours.

e. Frequency Distribution of Birthball with Intensity of Pain

Table 4.5 Frequency Distribution of Birthball with Intensity of Pain

\begin{tabular}{|c|c|c|c|c|}
\hline & & \multicolumn{2}{|c|}{ Intensity of Pain } & \multirow{2}{*}{ Total } \\
\hline & & Mild & Severe & \\
\hline \multirow{4}{*}{ Birthball } & Using & 16 & 4 & 20 \\
\hline & Using & $40 \%$ & $10 \%$ & $50 \%$ \\
\hline & NotIsino & 5 & 15 & 20 \\
\hline & NotUsing & $12,5 \%$ & $37,5 \%$ & $50 \%$ \\
\hline \multirow{2}{*}{ Total } & & 21 & 19 & 40 \\
\hline & & $52,5 \%$ & $47,5 \%$ & $100 \%$ \\
\hline
\end{tabular}

The relationship between birthballs and the intensity of pain is distributed as follows:

1) Respondents who used birthballs were distributed as follows: 16 respondents (40\%) with mild pain and 4 respondents $(10 \%)$ with severe pain.

2) Respondents who did not use birthballs were distributed as follows: 5 respondents with pain $(12.5 \%)$ with mild and 15 respondents $(37,5 \%)$ with severe pain.

2. Hypothesis testing

a. The Relationship of the Birth Ball with the Duration of the First Stage of Labor

Table 4.6 Relationshipof the BirthBall with the Duration of the First Stage of Labor

\begin{tabular}{|c|c|c|c|c|c|}
\hline & Value & df & $\begin{array}{l}\text { Asymp. } \\
\text { Sig. (2- } \\
\text { sided) }\end{array}$ & $\begin{array}{l}\text { Exact Sig. } \\
\text { (2-sided) }\end{array}$ & $\begin{array}{l}\text { Exact } \\
\text { Sig. (1- } \\
\text { sided) }\end{array}$ \\
\hline Pearson Chi-Square & $10.000^{\mathrm{a}}$ & 1 & .002 & \multirow{6}{*}{.004} & \multirow{6}{*}{.002} \\
\hline $\begin{array}{l}\text { Continuity } \\
\text { Correction }^{b}\end{array}$ & 8.100 & 1 & .004 & & \\
\hline Likelihood Ratio & 10.465 & 1 & .001 & & \\
\hline Fisher's Exact Test & & & & & \\
\hline $\begin{array}{l}\text { Linear-by-Linear } \\
\text { Association }\end{array}$ & 9.750 & 1 & .002 & & \\
\hline $\mathrm{N}$ of Valid Cases ${ }^{\mathrm{b}}$ & 40 & & & & \\
\hline
\end{tabular}

b. The Relationship of the Birth Ball with Intensity of Pain

Table 4.7 TheRelationship of the Birth Ball with Intensity of Pain

\begin{tabular}{|c|c|c|c|c|c|c|}
\hline & & Value & $\mathrm{df}$ & $\begin{array}{l}\text { Asymp. } \\
\text { Sig. (2- } \\
\text { sided) }\end{array}$ & $\begin{array}{l}\text { Exact Sig. } \\
\text { (2-sided) }\end{array}$ & $\begin{array}{l}\text { Exact } \\
\text { Sig. (1- } \\
\text { sided) }\end{array}$ \\
\hline $\begin{array}{l}\text { Pearson } \\
\text { Square }\end{array}$ & Chi- & $12.130^{\mathrm{a}}$ & 1 & .000 & & \\
\hline $\begin{array}{l}\text { Continuity } \\
\text { Correction }^{\text {b }}\end{array}$ & & 10.025 & 1 & .002 & & \\
\hline Likelihood F & Ratio & 12.842 & 1 & .000 & & \\
\hline
\end{tabular}




\section{STRADA Jurnal Ilmiah Kesehatan}

DOI: $10.30994 /$ sjik.v9i2.404

ISSN: 2252-3847 (print); 2614-350X (online)

Vol.9 No.2 November 2020 Page.981-989

Fisher's Exact

Test

.001

.001

Linear-by-Linear

Association

$\begin{array}{lll}11.827 & 1 & .001\end{array}$

$\mathrm{N}$ of Valid Cases ${ }^{\mathrm{b}} \quad 40$

c. The Relationship of the Birth Ball withthe Duration of the First Stage of Labor and Intensity of Pain

Tabel 4.8 Variables in The Equation

\begin{tabular}{|c|c|c|c|c|c|c|c|c|c|}
\hline & & \multirow[t]{2}{*}{$B$} & \multirow[t]{2}{*}{$\begin{array}{l}\text { Std. } \\
\text { Error }\end{array}$} & \multirow[t]{2}{*}{ Wald } & \multirow[t]{2}{*}{$\mathrm{df}$} & \multirow[t]{2}{*}{ Sig. } & \multirow[t]{2}{*}{$\operatorname{Exp}(B)$} & \multicolumn{2}{|c|}{$\begin{array}{l}95 \% \\
\text { Confidence } \\
\text { Interval for } \\
\operatorname{Exp}(B)\end{array}$} \\
\hline & & & & & & & & Lower & Upper \\
\hline \multirow{3}{*}{ Step $1^{\mathrm{a}}$} & Duration & 1.648 & .811 & 4.132 & 1 & .042 & 5.196 & 1.061 & $\begin{array}{l}25.45 \\
4\end{array}$ \\
\hline & Pain & 2.025 & .814 & 6.190 & 1 & .013 & 7.576 & 1.537 & $\begin{array}{l}37.34 \\
9\end{array}$ \\
\hline & Constant & -5.443 & 1.644 & 10.957 & 1 & .001 & .004 & & $\begin{array}{l}25.45 \\
4\end{array}$ \\
\hline
\end{tabular}

\section{DISCUSSIONS}

1. Frequency Distribution

a. The Birth Ball

Based on table 4.1, the frequency distribution showed that 20 respondents $(50 \%)$ used the birthballand 20 respondents $(50 \%)$ did not use the birthball.

In accordance with the objectives of the study, which is to determine whether the birthball is effective in accelerating the duration of the first stage of labor and reducing the intensity of pain, the researchers divided the respondents into 2 groups, which were the treated group and the untreated group. The number of respondents was 40, in which 20 respondents used birthballs and 20 respondents did not use birthballs.

b. The Duration of the First Stage of Labor

The first stage of labor consists of two phases: 1. Latent phase: dilating from 1 to 3 $\mathrm{cm}$, which lasts about 8 hours. 2. Active phase: dilatingfrom 3 to $10 \mathrm{~cm}$ (complete), 


\section{STRADA Jurnal Ilmiah Kesehatan}

DOI: $10.30994 /$ sjik.v9i2.404

ISSN: 2252-3847 (print); 2614-350X (online)

Vol.9 No.2 November 2020 Page.981-989

which lasts about 6 hours. In the active phase, the mother will feel contractions every 10 minutes for 20-30 seconds (Setyaputri, 2018).

Based on table 4.2 of the frequency distribution of the duration of the first stage of labor, 20 respondents experienced the duration of the first stage of laborfor less than and equal to 14 hours and 20 respondents experienced the duration of the first stage of laborfor more than 14 hours.

c. Intensity of Pain

The intensity of the pain (pain scale) is a description of how severe the pain is felt by an individual. The measurement of the intensity of pain is very subjective and individual and the possibility of pain in the same intensity is felt very differently by two different people. Pain intensity can be measured with a pain scale, which is a scale of 0-5 of mild pain and a scale of 6-10 of severe pain (Runjati, 2018).

Based on Table 4.3 of the frequency distribution of intensity of pain, 21 respondents felt mild pain, in which 10 respondents on a scale of 3, 6 respondents on a scale of 4 , and 7 respondents on a scale of 5 .

2. The Relationship of the Birthball with the Duration of the First Stage of Labor

\begin{tabular}{|c|c|c|c|c|c|}
\hline & Value & df & $\begin{array}{l}\text { Asymp. } \\
\text { Sig. } \\
\text { sided })\end{array}$ & $\begin{array}{l}\text { Exact Sig. } \\
\text { (2-sided) }\end{array}$ & $\begin{array}{l}\text { Exact } \\
\text { Sig. (1- } \\
\text { sided) }\end{array}$ \\
\hline $\begin{array}{l}\text { Pearson } \\
\text { Square }\end{array}$ & $10.000^{\mathrm{a}}$ & 1 & .002 & & \\
\hline $\begin{array}{l}\text { Continuity } \\
\text { Correction }^{\mathrm{b}}\end{array}$ & 8.100 & 1 & .004 & & \\
\hline Likelihood Ratio & 10.465 & 1 & .001 & & \\
\hline $\begin{array}{l}\text { Fisher's Exact } \\
\text { Test }\end{array}$ & & & & .004 & .002 \\
\hline $\begin{array}{l}\text { Linear-by-Linear } \\
\text { Association }\end{array}$ & 9.750 & 1 & .002 & & \\
\hline $\mathrm{N}$ of Valid Cases ${ }^{\mathrm{b}}$ & 40 & & & & \\
\hline
\end{tabular}

The table above shows the sig value. (2-tailed) or probability (p) of 0.002 . The level of significance is $5 \%(0.05)$. Because the $\mathrm{p}$ value $<0.05$, it can be stated that there is a significant relationship between the birthball and the duration of the first stage of labor.

The first stage of labor consists of two phases: 1. Latent phase: dilating from 1 to $3 \mathrm{~cm}$, which lasts about 8 hours. 2. Active phase: dilating from 3 to $10 \mathrm{~cm}$ (complete), which lasts about 6 hours. In the active phase, the mother will feel contractions every 10 minutes for 20-30 seconds (Setyaputri, 2018).

Birthballs help the first stage of labor to be shorter. The mothers may sit on the ball and move their thighs to front, back, right, and left sides, and rotate. Using a birthball will position the mother perpendicular. With that position, the contractions will be stronger and more efficient. The gravity will help the lowest part of the fetus to press down on the cervix and help the cervix dilate faster (Runjati, 2018).

The birthball helps to dilate the pelvis wider, which results in significantly shorter laborduration. The birth ball is more effective to use regularly, long before the birth process (Ade, 2017). 


\section{STRADA Jurnal Ilmiah Kesehatan}

DOI: $10.30994 /$ sjik.v9i2.404

ISSN: 2252-3847 (print); 2614-350X (online)

Vol.9 No.2 November 2020 Page.981-989

3. The Relationship ofthe Birthballwith Intensity of Pain

\begin{tabular}{|c|c|c|c|c|c|}
\hline & Value & df & $\begin{array}{l}\text { Asymp. } \\
\text { Sig. (2- } \\
\text { sided) }\end{array}$ & $\begin{array}{l}\text { Exact Sig. } \\
\text { (2-sided) }\end{array}$ & $\begin{array}{l}\text { Exact } \\
\text { Sig. (1- } \\
\text { sided) }\end{array}$ \\
\hline $\begin{array}{l}\text { Pearson Chi- } \\
\text { Square }\end{array}$ & $12.130^{\mathrm{a}}$ & 1 & .000 & & \\
\hline $\begin{array}{l}\text { Continuity } \\
\text { Correction }^{\mathrm{b}}\end{array}$ & 10.025 & 1 & .002 & & \\
\hline Likelihood Ratio & 12.842 & 1 & .000 & & \\
\hline $\begin{array}{l}\text { Fisher's Exact } \\
\text { Test }\end{array}$ & & & & .001 & .001 \\
\hline $\begin{array}{l}\text { Linear-by-Linear } \\
\text { Association } \\
\mathrm{N} \text { of Valid Cases }\end{array}$ & $\begin{array}{l}11.827 \\
40\end{array}$ & 1 & .001 & & \\
\hline
\end{tabular}

The table above shows the sig value (2-tailed) or probability (p) of 0.000 . The level of significance is $5 \%(0.05)$. Because the $\mathrm{p}$ value $<0.05$, it can be stated that there is a significant relationship between the birthball and the intensity of pain.

Pain during labor has the highest degree of pain among the others. Many pregnant women are not ready to give birth because they imagine the pain that will be experienced during labor. However, several alternatives can be chosen todayto minimize the labor pain, one of which is the use of a birth ball (Potter, 2013).

The presence of diversion of the mind or distraction is associated with reduced response to pain in a person. By focusing on the client's attention and concentration on other stimuli, their awareness of pain decreases. When a mother who gives birth applies the use of the birth ball, her attention to pain will be distracted by physical activity by making patterned movements that make her feel comfortable and relaxed and can build the mother's confidence to coping with the pain she feels. Therefore, the pain felt by the mother can be reduced(Nyapatrien, 2016).

4. The Relationship ofthe Birthballwith the Duration of the First Stage of Labor and Intensity of Pain

\begin{tabular}{|c|c|c|c|c|c|c|c|c|c|}
\hline & & \multirow[t]{2}{*}{$B$} & \multirow[t]{2}{*}{$\begin{array}{l}\text { Std. } \\
\text { Error }\end{array}$} & \multirow[t]{2}{*}{ Wald } & \multirow[t]{2}{*}{$\begin{array}{l}\text { D } \\
\text { f }\end{array}$} & \multirow[t]{2}{*}{ Sig. } & \multirow[t]{2}{*}{$\operatorname{Exp}(B)$} & \multicolumn{2}{|c|}{$\begin{array}{l}95 \% \\
\text { Confidence } \\
\text { Interval for } \\
\operatorname{Exp}(B)\end{array}$} \\
\hline & & & & & & & & Lower & Upper \\
\hline \multirow{3}{*}{ Step $1^{\mathrm{a}}$} & Duration & 1.648 & .811 & 4.132 & 1 & .042 & 5.196 & 1.061 & $\begin{array}{l}25.45 \\
4\end{array}$ \\
\hline & Pain & 2.025 & .814 & 6.190 & 1 & .013 & 7.576 & 1.537 & $\begin{array}{l}37.34 \\
9\end{array}$ \\
\hline & Constant & -5.443 & 1.644 & 10.957 & 1 & .001 & .004 & & $\begin{array}{l}25.45 \\
4\end{array}$ \\
\hline
\end{tabular}




\section{STRADA Jurnal Ilmiah Kesehatan}

DOI: $10.30994 /$ sjik.v9i2.404

ISSN: 2252-3847 (print); 2614-350X (online)

Vol.9 No.2 November 2020 Page.981-989

Based on this table, the effect between the independent variables on the dependent variables is as follows:

\section{The Duration of the First Stage of Labor}

The duration of the first stage of labor shows a significance value (p) of 0.042 . Because $p$ $<0.05$, therefore $\mathrm{HO}$ is rejected, indicating that the birthball has a significant effect on the duration of the first stage of labor.

\section{Intensity of Pain}

The intensity of painshows a significance value $(\mathrm{p})$ of 0.013 . Because $\mathrm{p}<0.05$, therefore $\mathrm{H} 0$ is rejected, indicating that the birthball has a significant effect on the intensity of pain. Based on the table, it can be concluded that there is a significant relationship between the birthball and the duration of the first stage of labor and intensity of pain.

The use of birth balls facilitates mothers to carry out physical movements with a pattern of pelvic rocking, which can strengthen the abdominal muscles and waist; reduce pressure on the waist; reduce pressure on the bladder; assist mothers to relax so that it can reduce tension, which has an impact on minimizing labor pain felt by mothers. Patterned physical movements by pelvic rocking are also beneficial in increasing the pelvic outlet by up to $30 \%$, facilitating optimal perineal stretching, optimizing oxygen flow and blood circulation to the fetus, and giving an effective position for fetal descent so that the fetus can descend easily and quickly during labor and pain, and therefore, labor painis brief(Zaky, 2016).

\section{REFERENCE}

Ade, K., dkk. 2017. Efektifitas Latihan Birthball terhadap Penurunan Nyeri Persalinan Kala 1 Fase Aktif Pada Primigravida. JNKI, Vol. (5) 11-10

Bobak, Lowdermik, Jensen. 2005. Buku Ajar Keperawatan Maternitas (Maternity Nursing) . Jakarta. EGC.

Brunner and Sudddarth. (2002). Buku Ajar Keperawatan Medikal Bedah, edisi 8 Volume2. Jakara : EGC.

Farrer, H. (2001). Keperawatan Maternitas. Edisi 4., Vol 2, Alih Bahasa : dr. Andri Hartono. Jakarta : EGC.

Gau M-L, Chang C-Y, Tian S-H, Lin K-C. 2011. Effects of birth ball exercise on pain and self-efficacy during childbirth: A randomised controlled trial in Taiwan. http://linkinghub.elsevier.com/ retrieve/pii/S0266613811000192.

Henderson, C., Jones, K. 2006. Buku Ajar Konsep Kebidanan. Jakarta. EGC.

Hidayat. 2006. Asuhan Keperawatan Maternitas. Gramedia. Yogyakarta.

Leung, RW, dkk. 2013. Efficacy of Birth Ball on Labor Pain Relief: A Systematic Review and Meta-analysis. Journal Obstetric and Gynecology Research. Vol. 41, No. 11, pp. $1679-1686$

Maurenne. 2005. Birthing ball : http://mynaturalchildbirth.org/birthing-ball. diakses 17 Agustus 2019

Nicholas dan Helmick. 2000. Chilbirth education, practice research and theory, edition 2. Philadelphia London : WB Saunders.

Nyapatrien, 2016. Teknik Mengurangi Nyeri Persalinan. https://www.google.com/amp/s/nyapatrien.wordpress.com/2016/06/18/belajar/amp diakses tanggal 2 April 2020

Potter, P. A, Perry, A. G. (2005). Buku Ajar Fundamental Keperawatan : Konsep. Proses, dan Praktik Edisi Ke 4.Volume 1. Alih Bahasa : Yasmin Asih, dkk. Jakarta. EGC

Potter, P. A. \& Perry, A. G. 2013. Buku Ajar Fundamental Keperawatan. Jakarta : EGC 


\section{STRADA Jurnal Ilmiah Kesehatan}

DOI: $10.30994 /$ sjik.v9i2.404

ISSN: 2252-3847 (print); 2614-350X (online)

Vol.9 No.2 November 2020 Page.981-989

Prawirohardjo, S. (2008). Ilmu Kandungan. Edisi Ketiga Cetakan Ketujuh. Jakarta : Yayasan Bina Pustaka Sarwono Prawirohardjo.

Prodi Keperawatan SK UB. 2012. Birth Ball, Pengaruh Terapi Birth Ball Terhadap Nyeri Persalinan. Malang. Diakses tgl 31 Juli 2017.

Runjati, S. U. 2018. Kebidanan Teori dan Asuhan. Jakarta: EGC

Setiaputri, K. 2018. Sebenarnya Buat Apa Pakai Birthball Selama Masa Kehamilan dan Persalinan?. www.hallosehat.com/manfaat-brth-ball-untuk-ibu-hamil/\%3famp Diakses tanggal 2 April 2020.

Yuliatun, L. 2008. Penanganan Nyeri Persalinan Dengan Metode Nonfarmakologi. Malang. Bayumedia Publising.

Zaky, N. H. 2016. Effect of Pelvic Rocking Exercise Using Sitting Possition on Birth Ball during The First Stage of Labor on Its Progress. IOSR Journal Of Nursing and Health Science (IOSR-JNHS. Vol. 5, No. 4, Ver. III. Pp. 19-27) 